\title{
Skeletal density and growth form of corals
}

\author{
Terence P. Hughes
}

Department of Biological Sciences, University of California, Santa Barbara, California 93106, USA

\begin{abstract}
This paper explores inter-specific variation in the density of coral skeletons. I present new data on the porosity of 7 species of reef-building scleractinians, and briefly review 20 previous studies on approximately 23 additional corals. Although the total number of species examined so far is still small, the review reveals a consistent pattern of skeletal density among different morphological groups of corals. The most porous corals are massive or bushy. Delicate foliaceous corals are the most dense. Tall branching corals exhibit a marked axial gradient in density, i.e. growing tips are very porous while basal regions are extremely dense. These results are consistent with differences in the mechanical requirements of various colony shapes.
\end{abstract}

\section{INTRODUCTION}

Scleractinian corals have complex porous skeletons. The question of why the skeletons of some corals are naturally more porous (i.e. less dense) than others has puzzled reef workers for some time. Earlier studies postulated a negative relation between coral density and growth rate (e.g. Vaughan 1915) and susceptibility to boring (Connell 1973), but recently these hypotheses have been rigorously tested for the first time, and refuted (Highsmith 1981). The mechanical consequences of the presence of pores in an otherwise solid structure include a sharp decline in compressive and tensile strength, and in stiffness (e.g. Wainright et al. 1976, Chamberlain 1978, Tunnicliffe 1979, Schuhmacher \& Plewka 1981). These properties may also limit the size or growth form of a coral colony. Therefore, I propose to test here the hypothesis that variation in skeletal density may be related in part to interspecific differences in colony shape.

The most common growth forms exhibited by corals are branching, massive and foliaceous (e.g. Jackson \& Hughes 1985). Branching corals, especially taller species, grow rapidly at their branch tips (e.g. Oliver et al. 1983, Tunnicliffe 1983), but are often easily broken during storms (Woodley et al. 1981). In some species, branch fragments may survive and propagate to form large clones (Highsmith 1982). In contrast, massive corals usually grow rather slowly (Connell 1973), and relatively uniformly (Land et al. 1975), over their hemispherically shaped surfaces. Because of their large basal area, massive colonies survive extreme wave action which can destroy other growth forms (Woodley et al. 1981). Foliaceous corals form horizontally flattened, unifacial plates or lobes that are attached to the reef substrate from the basal (ventral) surface. Their flattened shape results from a strong tendency for radial (i.e. edgej rather than vertical extension (Dustan 1975, Hughes \& Jackson 1985). Foliaceous corals are often thin and delicate, and many are found only in relatively calm, deep water (Goreau \& Wells 1967).

In this paper, I first examine gross morphological differences among 7 species of foliaceous corals (Agaricia agaricites, A. fragilis, A. lamarcki, A. undata, Leptoseris cucullata, Porites astreoides, and Montastrea annularis), and then review measurements on approximately 20 other coral species with a wide variety of colony forms. My purpose is 2-fold: first, to quantify the extent of inter-specific variation in the skeletal density of corals, and second, to search for patterns which might indicate why such variation has evolved.

The density of a coral skeleton is a conservative variable, because it is constrained by a strictly defined upper limit of $2.94 \mathrm{~g} \mathrm{~cm}^{-3}$, corresponding to the density of solid aragonitic $\mathrm{CaCO}_{3}$. Pores in the skeleton will effect a reduction from that maximum value, but there presumably must also be a minimum density caused by mechanical or other constraints. Therefore, interspecific differences in density might be expected to be small. Nevertheless, the data show that there are striking differences in skeletal density (more than 3 fold) between coral species, and indicate that much of 
this variation is correlated with differences in growth form.

\section{METHODS}

Colonies of the 7 species of foliaceous corals were collected from depths of $5,10,20,30$ and $40 \mathrm{~m}$ at Rio Bueno, on the north coast of Jamaica. Although the primary purpose of the collections was to search for differences in morphology between species, intraspecific variation was also examined over the depth range of each species. Three of the species, Agaricia agaricites, Montastrea annularis and Porites astreoides are highly polymorphic, typically exhibiting a gradual change from massive or knobby colonies to foliaceous forms with increasing depth. Only foliaceous colonies were collected in the present study since the skeletal density of massive colonies of these 3 taxa is already well known (Baker \& Weber 1975, Dustan 1975, Stearn et al. 1977, Chamberlain 1978, Highsmith et al. 1983, Tunnicliffe 1983, Dodge \& Brass 1984).

Colonies with a maximum diameter smaller than $10 \mathrm{~cm}$ were avoided to control for changes in the ratio of surface area to volume associated with ontogeny. (The ratio of the surface area of the base of an inverted cone divided by its volume changes little above a radius of $5 \mathrm{~cm}$ [e.g. Fig. 3 in Porter (1976)], especially where the maximum height of the cone is less than about one fourth of the diameter.) One-way ANOVA's of the collections confirm no significant differences in colony diameter among depths or species.

Only corals with a complete covering of tissue (which in these foliaceous species is primarily limited to their upper surfaces), were collected to reduce variation caused by bioerosion. Colonies were dried in the sun, and their undersurfaces cleaned of epibionts. Corals with excavations resulting from bioerosion were discarded. Because each species was rare at either shallow or deep sites, the number of sampled depths varied from 1 to 4 per species. Therefore, empty cells (not just missing values) preclude the use of a 2 -way ANOVA, so the effects of species and depth were examined separately. The number of colonies analyzed per species per depth ranged from 5 to 17 , giving a total of 207 .

Two quantitative traits of coral morphology were measured: skeletal density, and the ratio of surface area of tissue to skeletal mass. Both relate to the way a coral uses calcium carbonate to manufacture its skeleton. The latter is a measure of the amount of skeletal material required by a coral to occupy a given amount of space, and has obvious ecological as well as morphological importance. Each coral was photographed on land with a scale, and the photographs were digitized to obtain the area of the upper surface. Skeletal density of whole colonies was measured using Archimedes' Principle by weighing them first in air and then suspended briefly from an analytic balance into freshwater (Graus \& MacIntyre 1982). Skeletal volume was estimated as air weight divided by density.

\section{RESULTS}

In general, differences between the 7 foliaceous species in skeletal density were far greater than intraspecific variation within and between depths (Table 1). Porites astreoides was the most porous throughout its depth range from 5 to $30 \mathrm{~m}$, while Montastrea annularis consistently ranked second. Colonies of

Table 1. Mean skeletal density $\pm S E\left(\mathrm{~g} \mathrm{~cm}^{-3}\right)$ of foliaceous corals from Rio Bueno, Jamaica. Numbers in parentheses indicate number of colonies in each sample (total 207). Depth and species differences indicated by Kruskall-Wallace test. Blanks indicate approximate depth distribution of these species at Rio Bueno

\begin{tabular}{|c|c|c|c|c|c|}
\hline Species & $5 \mathrm{~m}$ & $10 \mathrm{~m}$ & $20 \mathrm{~m}$ & $30 \mathrm{~m}$ & $40 \mathrm{~m}$ \\
\hline $\begin{array}{l}\text { Porites astreoides } \\
\text { (ns) }\end{array}$ & $\begin{array}{c}1.69 \pm 0.02 \\
(10)\end{array}$ & $\begin{array}{c}1.62 \pm 0.03 \\
(10)\end{array}$ & $\begin{array}{c}1.68 \pm 0.04 \\
(12)\end{array}$ & $\begin{array}{c}1.67 \pm 0.03 \\
(10)\end{array}$ & - \\
\hline $\begin{array}{l}\text { Agaricia agaricites } \\
(p<0.001)\end{array}$ & $1.91 \pm 0.04$ & $\begin{array}{c}1.99 \pm 0.02 \\
(14)\end{array}$ & $\begin{array}{c}2.08 \pm 0.06 \\
(10)\end{array}$ & $\begin{array}{c}2.14 \pm 0.03 \\
(7)\end{array}$ & - \\
\hline $\begin{array}{l}\text { Montastrea annularis } \\
(\mathrm{p}<0.01)\end{array}$ & - & $\begin{array}{l}1.78 \pm 0.04 \\
(10)\end{array}$ & $\begin{array}{l}1.95 \pm 0.03 \\
\quad(10)\end{array}$ & $\begin{array}{c}2.05 \pm 0.04 \\
(9)\end{array}$ & - \\
\hline $\begin{array}{l}\text { Leptoseris cucullata } \\
\text { (ns) }\end{array}$ & - & $2.15 \pm 0.06$ & $\begin{array}{c}2.26 \pm 0.04 \\
(10)\end{array}$ & $\begin{array}{l}2.29 \pm 0.05 \\
(10)\end{array}$ & $2.25 \pm 0.05$ \\
\hline $\begin{array}{l}\text { Agaricia lamarcki } \\
\text { (ns) }\end{array}$ & - & - & $\begin{array}{l}2.30 \pm 0.03 \\
(10)\end{array}$ & $\begin{array}{c}2.25 \pm 0.04 \\
(17)\end{array}$ & $\begin{array}{c}2.31 \pm 0.03 \\
(12)\end{array}$ \\
\hline $\begin{array}{l}\text { Agaricia undata } \\
\text { (ns) }\end{array}$ & - & - & - & $2.46 \pm 0.03$ & $\begin{array}{c}2.44 \pm 0.06 \\
(6)\end{array}$ \\
\hline \multirow[t]{2}{*}{ Agaricia fragilis } & - & - & - & - & $\begin{array}{c}2.31 \pm 0.05 \\
(11)\end{array}$ \\
\hline & $p<0.001$ & $p<0.001$ & $p<0.001$ & $\mathrm{p}<0.001$ & (ns) \\
\hline
\end{tabular}


Agaricia spp. and Leptoseris cucullata were much more dense, especially in deep water. At $30 \mathrm{~m}$, where collections of 6 species were taken, densities of A. undata, L. cucullata, A. lamarcki, A. agaricites and M. annularis were on average $47,37,35,28$ and $23 \%$ greater, respectively, than $P$. astreoides (KruskallWallace test, $\mathrm{p}<0.001$, Table 1 ).

Skeletal density of foliaceous Agaricia agaricites and Montastrea annularis increased significantly with depth (Table 1). The change was modest, amounting to an average increase of $12 \%$ from 5 to $30 \mathrm{~m}$ in $A$. agaricites, and of $15 \%$ from 10 to $30 \mathrm{~m}$ in foliaceous $M$. annularis (Kruskall-Wallace test, $p<0.001$ and $p<0.01$ respectively). In contrast, the remaining species showed no significant change in density over their depth range.

The foliaceous species also differed greatly in the area of substrate covered per unit weight of skeleton (Table 2). The characteristically thick plates of Montastrea annulanis had by far the lowest value of all wherever it was collected, while the more delicate Leptoseris cucullata had the highest ratio throughout its depth range. Where they were both collected, from 10 to $30 \mathrm{~m}, L$. cucullata covered the same amount of substrate with 4 to 5 times less skeletal mass than $M$. annularis, despite the considerably higher density of $L$. cucullata. Thus, the range between foliaceous species in surface area per unit weight of skeleton (from 0.39 to $2.14 \mathrm{~cm}^{2} \mathrm{~g}^{-1}$ ) was approximately 10 times greater than the more modest differences in density (ranging from 1.62 to $2.46 \mathrm{~g} \mathrm{~cm}^{-3}$ ).

There was a significant increase of surface area to weight ratios with depth among 2 species, Agaricia agaricites and $A$. lamarcki (Table 2). A. agaricites at $30 \mathrm{~m}$ covers the same area with an average of almost half the weight of skeleton than at $5 \mathrm{~m}$. Similarly, $A$. lamarcki at $40 \mathrm{~m}$ occupies the same amount of space with one third less skeletal mass than at $20 \mathrm{~m}$. Leptoseris cucullata and A. undata showed similar trends, but they were not statistically significant. These changes were not due to a decline in skeletal density at greater depths, since density of each species either stayed the same or increased in deeper water (Table 1). Rather, the surface areas per mass of skeleton increased because deeper foliaceous corals were substantially thinner. This pattern of increasing flattening of corals also occurred inter-specifically (Table 2), as relatively robust species predominating in shallow water (e.g. Porites astreoides, A. agaricites and Montastrea annularis) were replaced by thinner, more delicate ones at greater depths (e.g. by $A$. undata and $A$. fragilis).

\section{DISCUSSION AND REVIEW}

Previous estimates of skeletal density are summarized in Table 3. (Several studies that were based on only a single colony or an unknown number of specimens were omitted.) I have divided the corals into 3 major categories, namely, branching, massive and foliaceous growth forms. Before describing the patterns, I should caution that some of the variation in the reported densities of corals may be due to differences in sampling and measurement techniques. For example, the size and position of each sample is important. Larger specimens will give smaller measurement errors of weight or displacement, but they are also more likely to be excavated by borers. In addition, colony extremities such as branch tips are often extremely porous compared to basal parts of branching colonies. At a smaller scale, cores or slabs of a few grams may differ in density because of their location in relation to individual calices or seasonal banding

Table 2. Area/weight ratio $\left(\mathrm{cm}^{2} \mathrm{~g}^{-1}\right) \pm \mathrm{SE}$ of foliaceous corals from Rio Bueno, Jamaica. See Table 1 for explanation

\begin{tabular}{|c|c|c|c|c|c|}
\hline Species & $5 \mathrm{~m}$ & $10 \mathrm{~m}$ & $20 \mathrm{~m}$ & $30 \mathrm{~m}$ & $40 \mathrm{~m}$ \\
\hline $\begin{array}{l}\text { Porites astreoides } \\
\text { (ns) }\end{array}$ & $\begin{array}{l}0.78 \pm 0.06 \\
(10)\end{array}$ & $\begin{array}{l}0.78 \pm 0.05 \\
(10)\end{array}$ & $\begin{array}{l}0.78 \pm 0.08 \\
(12)\end{array}$ & $\begin{array}{c}0.75 \pm 0.07 \\
(10)\end{array}$ & - \\
\hline $\begin{array}{l}\text { Agaricia agaricites } \\
(p<0.001)\end{array}$ & $\begin{array}{c}0.53 \pm 0.04 \\
(8)\end{array}$ & $\begin{array}{c}0.78 \pm 0.09 \\
(14)\end{array}$ & $\begin{array}{c}0.88 \pm 0.05 \\
(10)\end{array}$ & $1.06 \pm 0.07$ & - \\
\hline $\begin{array}{l}\text { Montastrea anmularis } \\
\text { (ns) }\end{array}$ & - & $\begin{array}{l}0.41 \pm 0.02 \\
(10)\end{array}$ & $\begin{array}{c}0.39 \pm 0.03 \\
(10)\end{array}$ & $\begin{array}{c}0.47 \pm 0.04 \\
(10)\end{array}$ & - \\
\hline $\begin{array}{l}\text { Leptoseris cucullata } \\
\text { (ns) }\end{array}$ & - & $\begin{array}{c}1.50 \pm 0.19 \\
(13)\end{array}$ & $\begin{array}{l}2.05 \pm 0.18 \\
(12)\end{array}$ & $\begin{array}{c}1.97 \pm 0.18 \\
(10)\end{array}$ & $\begin{array}{c}2.14 \pm 0.29 \\
(5)\end{array}$ \\
\hline $\begin{array}{l}\text { Agaricia lamarcki } \\
(\mathrm{p}<0.05)\end{array}$ & - & - & $\begin{array}{l}0.98 \pm 0.07 \\
(10)\end{array}$ & $\begin{array}{c}1.16 \pm 0.07 \\
(17)\end{array}$ & $\begin{array}{c}1.33 \pm 0.06 \\
(12)\end{array}$ \\
\hline $\begin{array}{l}\text { Agaricia undata } \\
\text { (ns) }\end{array}$ & - & - & - & $\begin{array}{c}1.57 \pm 0.12 \\
(7)\end{array}$ & $\begin{array}{c}1.74 \pm 0.09 \\
(6)\end{array}$ \\
\hline \multirow[t]{2}{*}{ Agaricia fragilis } & - & - & - & - & $\begin{array}{c}1.28 \pm 0.16 \\
(11)\end{array}$ \\
\hline & $p<0.001$ & $p<0.001$ & $\mathrm{p}<0.001$ & $p<0.001$ & $p<0.001$ \\
\hline
\end{tabular}


Table 3. Summary of coral densities

\begin{tabular}{|c|c|c|c|c|c|c|}
\hline Species & Morphology & $\begin{array}{l}\text { Density } \\
\left(\mathrm{g} \mathrm{cm}^{-3}\right)\end{array}$ & $\begin{array}{c}\text { Depth } \\
(\mathrm{m})\end{array}$ & Site & Remarks & Source \\
\hline \multicolumn{7}{|l|}{ Ramose corals } \\
\hline Acropora cervicornis & Erect & $0.15-2.80$ & 8 & St. Croix & Axial gradient & Gladfelter 1982 \\
\hline Acropora cervicornis & Erect & $1.20-2.48$ & $5.5-27$ & Jamaica & Axid gradient & Tunniclife 1983 \\
\hline Acropora cervicomis & Erect & $1.79-2.18$ & $?$ & Jamaica & Axial gradient & Schuhmacher \& Plewka 1981 \\
\hline Acropora formosa & Erect & $0.5-2.6$ & $5-15$ & Davies Reef, GBR & Axial gradient & Oliver et al. 1983 \\
\hline Acropora palmata & Erect & $1.47-2.23$ & $?$ & Jamaica & Axial gradient & Schuhmacher \& Plewka 1981 \\
\hline Acropora palmata & Erect & $0.82-2.41$ & $<10$ & Caribbean & Axial gradient & Shapiro 1980 \\
\hline Acropora palmata & Erect & 2.02 & $<10$ & Caribbean & & Chamberlain 1978 \\
\hline Eusmilia fastgiata & Short branches & 1.30 & $7-12$ & Caribbean & & Tunnicliffe unpubl. \\
\hline Madracis mirabilis & Short branches & 1.68 & $7-15$ & Caribbean & & Tunnicliffe unpubl. \\
\hline Porites furcata & Short branches & 1.05 & $<3$ & St Croix & $30 \%$ seasonal change & Meyer \& Schultz 1985 \\
\hline Porites porites & Short branches & 1.18 & $0-5$ & Barbados & & Stearn et al. 1977 \\
\hline Tubastrea aurea & Plocoid & 1.07 & $?$ & Pacafic & & Schuhmacher 1984 \\
\hline Tubastrea micranthus & Erect & $1.91-2.47$ & ? & Phillipines & Axıal gradient & Schuhmacher 1984 \\
\hline \multicolumn{7}{|c|}{ Massive (hemispherical or columnar) corals } \\
\hline Agaricia agaricites & & 1.87 & $0-5$ & Barbados & & Stearn et a]. 1977 \\
\hline Colpophyllia natans & Meandroid & 0.65 & $?$ & Jamaica & & Tunnicluffe 1983 \\
\hline Colpophyllia natans & Meandroid & 0.84 & $?$ & Caribbean & & Highsmith 1981 \\
\hline Diploria labrynthiformis & Meandroid & 1.57 & 1 & Bermuda & & Dodge \& Thomson 1974 \\
\hline Favia pallida & & 1.43 & $2-29$ & Enewetak & & Highsmith 1.979 \\
\hline Goniastrea retormis & & 1.70 & $6-17$ & Enewetak & & Highsmith 1.979 \\
\hline Montastrea annularis & & 1.28 & $2-8$ & St. Croix & $<10 \%$ seasonal change & Dodge \& Brass 1984 \\
\hline Montastrea annularis & & 1.41 & $0-5$ & Barbados & & Stearn et al. 1980 \\
\hline Montastrea annularis & & 1.47 & $?$ & Caribbean & & Chamberlain 1978 \\
\hline Montastrea annularis & & 1.58 & $0-4.5$ & St. Croix & & Baker \& Weber 1975 \\
\hline Montastrea annularis & & 1.79 & $9-13.5$ & St. Croux & Depth gradient & Baker \& Weber 1975 \\
\hline Montastrea annularis & & 1.71 & $8-24$ & Jamaica & & Dustan 1975 \\
\hline Montastrea annularis & & 1.81 & $1-30$ & Belize & Depth gradient & Graus \& Mclntyre 1982 \\
\hline Montastrea cavernosa & & 1.60 & $5-26$ & Belize & & Highsmith et al. 1983 \\
\hline Montipora berryi & & 1.58 & $?$ & Enewetak & & Highsmith 1981 \\
\hline Oulophyllia crispa & Meandrold & 0.98 & $?$ & Enewetak & & Highsmith 1981 \\
\hline Pavona clavus & & 1.86 & $5-7$ & Gulf of Chirıqui & $13 \%$ seasonal change & Wellington \& Glynn 1983 \\
\hline Pavona clavus & & 1.44 & $5-7$ & Gulf of Panama & 35 : seasonal change & Wellington \& Glynn 1983 \\
\hline Pavona gigantea & & 1.75 & $5-7$ & Gulf of Panama & $20 \%$ seasonal change & WeWngton \& Glynn 1983 \\
\hline Porites astreoides & & 1.48 & $1-15$ & Belize & & Highsmith et al. 1983 \\
\hline Porites astreoides & & 1.40 & $0-5$ & Barbados & & Stearn et al. 1977 \\
\hline Porites astreoides & & 1.26 & $<10$ & Jamaica & & Tunnicliffe 1.983 \\
\hline Porites lutea & & 1.41 & $0-29$ & Enewetak & & Highsmith 1979 \\
\hline Porites spp. (mostly) & & $1.30-1.65$ & $2-30$ & Enewetak & $10-30 \%$ seasonal change & Buddemeir et al. 1974 \\
\hline Porites spp. & & 1.20 & $5-10$ & Dahu & & Schneider \& Smith 1982 \\
\hline Porites spp. & & 1.60 & $5-10$ & Midway & $10-20 \%$ seasonal change & Schneider \& Smuth 1982 \\
\hline Porites spp. & & 1.70 & $?$ & Abrolhos Is. & & Schneider \& Smith 1982 \\
\hline Siderastrea radians & & 1.82 & $?$ & Caribbean & & Chamberlain 1978 \\
\hline Siderastrea siderea & & 1.61 & $0-5$ & Barbados & & Stearn et al. 1977 \\
\hline \multicolumn{7}{|c|}{ Foliaceous (or flattened) corals } \\
\hline Agaricia agaricites & Foliaceous & 2.02 & $5-30$ & Jamaica & Depth gradient & Table 1 \\
\hline Agaricia fragilis & Foliaceous & 2.31 & 40 & Jamaica & & Table 1 \\
\hline Agaricia lamarcki & Foliaceous & 2.28 & $20-40$ & Jamaica & & Table 1 \\
\hline Agaricia undata & Foliaceous & 2.45 & $30-40$ & Jamaica & & Table 1 \\
\hline Dichocoenia sp. & Flattened & 2.30 & ? & Jamaica & & Tunnicinffe 1983 \\
\hline Dichocoenia stokesi & Flattened & 2.04 & 2 & Caribbean & & Highsmith 1981 \\
\hline Leptoseris cucullata & Foliaceous & 2.24 & $10-40$ & Jamaica & & Table 1 \\
\hline Montastrea annularis & Foliaceous & 1.96 & $18-27$ & St. Croix & Depth gradient & Baker \& Weber 1975 \\
\hline Montastrea annularis & Foliaceous & 1.76 & $10-50$ & Jamaica & & Dustan 1975 \\
\hline Montastred annularis & Foliaceous & 1.92 & $10-30$ & Jamaica & Depth gradient & Table 1 \\
\hline Porites astreoides & Foliaceous & 1.67 & $5-30$ & Jamaica & & Table 1 \\
\hline
\end{tabular}


patterns. High and low density portions of annual bands typically vary in porosity by 10 to $35 \%$ (Buddemeier et al. 1974, Schneider \& Smith 1982, Wellington \& Glynn 1983, Meyer \& Schultz 1985).

Skeletal density may also depend on the depth of collection. For example, the densities of Montastrea annularis and Agaricia agaricites increased in deeper water (Table 1). This relation has been shown before for $M$. annularis by Baker \& Weber (1975), and by Graus \& MacIntyre (1982), although Dustan (1975) found no consistent trend. However, as noted here for foliaceous corals (Table 1), intraspecific variations in density associated with change in depth are usually small compared with inter-specific differences. Only 2 of the species examined here showed a detectable change in density over their depth range, while interspecific differences were highly significant at each sampled depth from 5 to $30 \mathrm{~m}$.

Various related mechanisms may combine to cause a depth gradient in skeletal densities. For example, an increase in spacing of polyps (fewer polyps per unit area) with increasing depth has been described in Dichocoenia stokesi (Wells 1973), Oculina varicosa (Reed 1983), Montastrea cavernosa (Lasker 1981) and Montastrea annularis (Weber et al. 1976, Dustan 1979). As noted by Highsmith (1981), the density of a coral is influenced by the spacing and size of corallites, i.e. by the ratio of wall thickness to corallite diameter. Therefore, more widely spaced polyps should result in higher skeletal density, all else being equal. In addition, the proportion of each annual band pair that is composed of high density skeleton has been shown to be greater in deeper water in Porites lutea (Highsmith 1979), and M. annularis (Baker \& Weber 1975). On a smaller scale, changes in density with depth may reflect variation in the micro-structure of skeletal elements (e.g. Foster 1979, 1980).

In spite of potential sources of variation, such as sampling technique or depth of collections, measurements of density made independently for the same species by different authors are usually fairly similar (Table 3). For example, Stearn et al. (1977) report a mean density of $1.87 \mathrm{~g} \mathrm{~cm}^{-3}$ for Agaricia agaricites at 0 to $5 \mathrm{~m}$, which agrees well with values of $1.91 \mathrm{~g} \mathrm{~cm}^{-3}$ at $5 \mathrm{~m}$ reported here (Table 1 ). The biggest intra-specific range is shown by 7 studies on the density of Montastrea annularis, that give mean values from 1.28 to $1.96 \mathrm{~g} \mathrm{~cm}^{-3}$ (Dustan 1975, Baker \& Weber 1975, Stearn et al. 1977, Chamberlain 1978, Graus \& MacIntyre 1982, Dodge \& Brass 1984; Table 1). However, even this considerable spread in values is small compared to inter-specific differences that span a 3 -fold range (Table 3). Note, furthermore, that the lowest reported densities of $M$. annularis come from studies conducted at shallow sites: $1.28 \mathrm{~g} \mathrm{~cm}^{-3}$ at depths of 2 to $8 \mathrm{~m}$ reported by Dodge \& Brass (1984), $1.41 \mathrm{~g} \mathrm{~cm}^{-3}$ at 0 to $5 \mathrm{~m}$ by Stearn et al. (1977), and $1.58 \mathrm{~g} \mathrm{~cm}^{-3}$ at 0 to $4.5 \mathrm{~m}$ by Baker \& Weber (1975). Baker \& Weber (1975) also reported densities of $1.79 \mathrm{~g} \mathrm{~cm}^{-3}$ at 9 to $13.5 \mathrm{~m}$ and of $1.96 \mathrm{~g} \mathrm{~cm}^{-3}$ at 18 to $27 \mathrm{~m}$, which closely match values for $M$. annularis of $1.78 \mathrm{~g} \mathrm{~cm}^{-3}$ at $10 \mathrm{~m}$ and 1.95 $\mathrm{g} \mathrm{cm}^{-3}$ at $20 \mathrm{~m}$ reported in Table 1 . This concurrence occurs even though Baker \& Weber's measurements were made from calibrated $X$-ray exposures (photodensitometry), while mine were obtained more crudely by wet and dry weighings.

\section{Branching corals}

The most consistent characteristic of the density of tall, loosely-branched corals (Table 3 ) is a marked axial gradient due to secondary infilling of skeletal pores in older portions of the colony (Gladfelter 1982, Oliver et al. 1983, Tunnicliffe 1983, Schuhmaker 1984, Wellington \& Trench 1985). Presumably, this is an adaptation that first allows rapid distal growth of branches (e.g. Tunnicliffe 1983, Oliver et al. 1983), which are later strengthened towards the base to avoid excessive breakage. Loosely branched corals are often broken up and passively dispersed during storms (Highsmith 1982). In moderate amounts, this process of asexual reproduction may be adaptive, but fragments that are too small are easily abraded and killed (Highsmith 1982, Hughes 1986).

Densities at the base of the staghorn corals Acropora cervicornis and $A$. formosa are the highest recorded for any scleractinian. However, the range of skeletal densities along a single branch of either of these species (Gladfelter 1982, Oliver et al. 1983, Tunnicliffe 1983), and in the closely related elkhorn coral $A$. palmata (Schuhmacher \& Plewka 1981) is enormous (Table 3). (The rather high density of $2.02 \mathrm{~g} \mathrm{~cm}^{-3}$ reported by Chamberlain [1978] for cylindrical cores of branching $A$. palmata is probably due to their proximal position within the colony.) The same axial pattern is found in Tubastraea micranthus, a tall, branching dendrophyliid which lacks zooxanthellae (Schuhmacher 1984, Wellington \& Trench 1985), indicating that this pattern of growth has evolved independently in morphologically similar, but distantly related, taxa. Because of these extreme intra-colony gradients, it is impossible to say whether the average densities of tall branching corals are significantly different from other morphologies. Clearly, the most striking trait of the group is the unique distribution pattern of skeletal material.

All of the erect species in Table 3 have extensive gastrovascular systems that ramify deeply into the skeleton (e.g. Fig. 2 in Gladfelter 1982, Fig. 2 in 
Wellington \& Trench 1985). Gladfelter (1982) proposed that this may be the means for inward transportation of ions required for mineralization, since non-perforate corals such as massive Montastrea spp. (which lack such an internal canal system) apparently do not exhibit comparable gradients in skeletal density (that is, on a spatial scale greater than a few millimeters, e.g. Schneider \& Smith 1982). Infilling in branching corals results in a uniformly high density in older (proximal) skeleton, and may obscure changes in density associated with season (i.e. banding) or depth (Tunnicliffe 1983, Gladfelter 1982, 1984). This is part of the reason why almost all banding studies have been conducted with massive corals.

There are apparently no corals with entirely porous skeletons that form tall branching colonies, and very few non-perforate ones. An example of the latter is the Caribbean pillar coral Dendrogyra cylindrus. As the name implies, this species forms extremely stout and vertical branches, which are up to an order of magnitude thicker than those of staghorn corals. D. cylindrus presumably has a uniformly high skeletal density to further reduce the likelihood of breakage, and grows much slower than branching acroporids (mean linear growth of $0.8 \mathrm{~cm} \mathrm{yr}^{-1}$ in Curaçao at $7 \mathrm{~m}$ depth: R.P.M. Bak pers. comm.).

Other ramose corals in Table 3, Eusmilia fastigiata, Madracis mirabilis, Porites furcata, $P$. porites and Tubastraea aurea, have much shorter branches than the taller species discussed above, and are generally much more porous. Up to $2 / 3$ of their skeleton is composed of cavities, and they have not yet been reported to show axial gradients in density. Because of their more bushy morphology, they are not subjected to the same degree of mechanical stress from wave action, since the force acting on the base of a branch depends on its length (Wainwright et al. 1976, p. 248). In addition, shorter branches positioned closer to the substrate may encounter reduced amounts of water movement because of the shelter afforded by taller neighbours.

\section{Massive corals}

Whole skeletons of massive corals were often the least dense of the 3 major morphological groups (branching, massive, and foliaceous) in Table 3. Two species, Colpophyllia natans and Oulophyllia crispa, have densities of less than $1 \mathrm{~g} \mathrm{~cm}^{-3}$. Both of these are brain corals, whose corallites are joined by common walls to form elongated valleys 10 to $15 \mathrm{~mm}$ across (Smith 1971, p. 83; Backhuys 1980, p. 68). A third brain coral, Diploria labrynthiformis, has narrow valleys which are on average only $5 \mathrm{~mm}$ across (Smith 1971, p. 81), and has a higher density of $1.56 \mathrm{~g} \mathrm{~cm}^{-3}$ (Dodge
\& Thompson 1974). Twelve other species of massive corals with distinct polyps (i.e. cerioid rather than meandroid coralla) have densities ranging from 1.20 to $1.87 \mathrm{~g} \mathrm{~cm}^{-3}$, with an average of $1.61 \mathrm{~g} \mathrm{~cm}^{-3}$. This range of values contrasts with $2.0 \mathrm{~g} \mathrm{~cm}^{-3}$ or more for most foliaceous corals (Mann-Whitney test, $\mathrm{p}<0.001$ ), and is also exceeded by the bases (but not the tips) of all tall branching corals. As a group, only bushy corals were less dense than massive colonies. (The mean for 5 bushy species was $1.26 \mathrm{~g} \mathrm{~cm}^{-3}$ versus $1.57 \mathrm{~g} \mathrm{~cm}^{-3}$ for all 16 massive species, Mann-Whitney test, $p<0.05$ ). Although massive colonies are relatively porous (Table 3), their hemispherical shape and wide basal area of attachment makes them highly resistant to damage from storms and hurricanes (e.g. review by Jackson \& Hughes 1985),

\section{Foliaceous corals}

Foliaceous corals as a group have the most dense skeletons yet reported for whole corals (Table 3 ). One obvious exception is the plate-like form of Porites astreoides, which like branching and massive poritids, is relatively porous even in deep water. Flattened plates of $P$. astreoides, and Montastrea annularis are thicker than deep-water species of Agaricia and Leptoseris (Table 2), and are commonly attached to the reef by a sustantially greater part of their undersurface. The low density of $P$. astreoides and $M$. annularis compared to that of the thin, but very dense, plates of Leptoseris and Agaricia species indicates there is an inverse relation between density and plate thickness, analogous to the increase in density among foliaceous versus massive corals (Table 3 ). Indeed, a hypothetical foliaceous coral as thin as $L$. cucullata but with the density of $P$. astreoides would probably fall apart as it grew under its own weight. Foliaceous corals in shallow water are easily damaged by storms (Hughes 1984), and the most common of these species on exposed reefs are those which grow fast and have high rates of recruitment, such as $A$. agaricites, $P$. astreoides and L. cucullata (Hughes \& Jackson 1985). Other species of Agaricia, Dichocoenia, and the plate-like morphology of $M$. annularis are most commonly found at depths greater than 15 to $20 \mathrm{~m}$ (Goreau \& Wells 1967, Jackson \& Hughes 1985).

There is no clear-cut relation between skeletal density and growth rates of the foliaceous species examined here. Growth rates of these and other species decline in deeper water (e.g. Baker \& Weber 1975, Dustan 1975, Hughes \& Jackson 1985, and many more), yet the density of Agaricia lamarcki, A. undata, Leptoseris cucullata, and Porites astreoides did not change significantly at greater depths (Table 1). The expected increase in density did occur among deep- 
water colonies of $A$. agaricites and Montastrea annularis, but the lack of a similar relation for the majority of the species indicates the correlation between growth and density is merely fortuitous. Furthermore, growth rates of $L$. cucullata and $P$. astreoides are very similar (Fig. 9 \& 10 in Hughes \& Jackson 1985) although these species differ greatly in density (Table 1 ). In addition, foliaceous $M$. annularis grows much slower than any species of Agaricia or $L$. cucullata (ibid), even though the former is more porous (Table 1). These results support Highsmith's (1981) conclusion that extension rates and skeletal density of corals are only very weakly correlated.

\section{CONCLUSIONS}

High density reduces the likelihood of breakage (e.g. Wainright et al. 1976, Chamberlain 1978, Schuhmacher 1984), and has evolved to the greatest degree in species with otherwise delicate morphologies, i.e. among tall branching and thin foliaceous corals (Table 3 ). Why are not all corals, including massive and bushy ones, equally dense? Presumably, there are trade-offs between skeletal density and other factors. For example, a higher density would be likely if there was a reduction in the size of a colony's corallites (or an increase in corallite spacing), so that the ratio of wall thickness to corallite diameter increased (Highsmith 1981). But such a remodeling might also affect the coral's ability to feed, compete for space, clean itself of sediment, or alter the size of its gonads. Since some of these changes may not be adaptive, the benefits of enhanced density may be outweighed by such potential 'costs'.

The density patterns shown here have probably persisted throughout the evolution of corals. Thus, as far as I am aware, meandroid and cerioid colonies with large polyps have always been encrusting or massive, never tree-like. Similarly, there are no extant or fossil examples of erect, loosely branching Porites spp. analogous to thickets of acroporid staghorn corals, nor are there any massive Acropora spp. that resemble poritid mounds. It seems likely that these evolutionary patterns are due in part to mechanical or developmental constraints reflected in the density trends described here.

Acknowledgements. I thank J. H. Connell, C. D'Antonio, J. B. C. Jackson, P. Ross, E. Schultz, and R. K. Trench for their support and comments. V. Tunnicliffe and R. P. M. Bak generously provided unpublished data. Collection of the foliaceous corals was made possible by the help of $\mathrm{M}$. J. Boyle, F. Jeal and C. Nolan. This study was supported by NSF grants OCE 82-15469 to J. B. C. Jackson, OCE 84-08610 to J. $\mathrm{H}$. Connell, and by a grant from the American Philosophical
Society to T. P. Hughes. This is contribution no. 374 of the Discovery Bay Marine Laboratory, Jamaica.

\section{LITERATURE CITED}

Baker, P. A., Weber, J. N. (1975). Coral growth rate: variation with depth. Earth Planet. Sci. Lett. 27: 57-61

Buddemeier, R. W. Maragos, J. E., Knudson, D. W. (1974). Radiographic studies of reef coral exo-skeletons: rates and patterns of coral growth. J. exp. mar. Biol. Ecol. 14: 179-200

Chamberlain, J. A. Jr. (1978). Mechanical properties of coral skeleton: compression strength and its adaptive significance. Paleobiol. 4: 419-435

Connell, J. H. (1973). Population ecology of reef building corals. In: Jones, O. A., Endean, R. (ed.) Biology and geology of coral reefs, Vol. 2. Academic Press, New York, p. $205-245$

Ditlev, H. (1980). A field guide to the reef-building corals of the Indo-Pacific. Scandinavian Science Press Ltd., Klampenborg

Dodge, R. E., Brass, G. W. (1984). Skeletal extension, density and calcification of the reef coral, Montastrea annularis: St. Croix, U.S. Virgin Islands. Bull mar. Sci. 34 (2): 288-307

Dodge, R. E., Thomson, J. (1974). The natural radiochemical and growth records in contemporary hermatypic corals from the Atlantic and Caribbean. Earth Planet. Sci. Lett. 23: $313-322$

Dustan, P. (1975). Growth and form in the reef-building coral M. annularis. Mar. Biol. 33: 101-107

Dustan, P. (1979). Distribution of zooxanthellae and photosynthetic chloroplast pigments of the reef-building coral Montastrea annularis (Ellis and Solander) in relation to depth on a West Indian coral reef. Bull. mar. Sci. 29 (1): 79-95

Foster, A. B. (1979). Phenotypic plasticity in the reef corals Montastrea annularis (Ellis and Solander) and Siderastrea siderea (Ellis and Solander). J. exp. Mar. Biol. Ecol. 39. 25-54

Foster, A. B. (1980). Environmental variation in skeletal morphology within the Caribbean reef corals Montastrea annularis and Siderastrea siderea. Bull. mar. Sci. 30 (3): 678-709

Gladfelter, E. H. (1982). Skeletal development in Acropora cervicornis I. Patterns of calcium carbonate excretion in the axial corallite. Coral Reefs 1: 45-51

Gladfelter, E. H. (1984). Skeletal development in Acropora cervicornis. III. A comparison of monthly rates of linear extension and calcium carbonate accretion measured over a year. Coral Reefs $3: 51-57$

Goreau, T. F., Wells, J. W. (1967). The shallow-water Scleractinia of Jamaica: Revised list of species and their vertical distribution range. Bull. mar. Sci. 17 (2): 442-453

Graus, R. R., MacIntyre, I. G. (1982). Variation in growth forms of the reef coral $M$. annularis (Ellis \& Solander): a quantitative evaluation of growth response to light distribution using computer simulation. In: Rützler, K., Macintyre, I. G. (ed.) The Atlantic Barrier Reef ecosystem at Carrie Bow Cay, Belize. I. Structure and communities. Smithson. Contr. mar. Sci. 12: 441-464

Highsmith, R. (1979). Coral growth rates and environmental control of density banding. J. exp. mar. Biol. Ecol. 37 : 105-125

Highsmith, R. C. (1981). Coral bioerosion: damage relative to skeletal density. Am. Nat. 117 (2): 193-198 
Highsmith, R. C. (1982). Reproduction by fragmentation in corals. Mar Ecol. Prog. Ser. 7: 207-226

Highsmith, R. C., Lueptow, R. L., Schonberg, S. C. (1983). Growth and bioerosion of three massive corals on the Belize barrier reef. Mar Ecol. Prog. Ser. 13: 261-271

Hughes, T. P. (1984). Population dynamics based on individual size rather than age: a general model with a reef coral example. Am. Nat. 123: 778-795

Hughes, T. P. (1986). Life histories and population dynamics of early successional corals. Proc. 5th Int. Coral Reef Congress, Tahiti 4: 101-106

Hughes, T. P., Jackson, J. B. C. (1985). Population dynamics and life histories of foliaceous corals. Ecol. Monogr. 55 (2): 141-166

Jackson, J. B. C., Hughes, T. P. (1985). Adaptive strategies of coral-reef invertebrates. Am. Scient. 73: 265-274

Land, L., Lang, J., Barnes, D. (1975). Extension rate: a primary control on the isotopic composition of West Indian (Jamaican) scleractinian reef coral skeletons. Mar. Biol. 33: 221-233

Lasker, H. R. (1981). Phenotypic variation in the coral Montastrea cavernosa and its effects on colony energetics. Biol. Bull. mar. biol Lab., Woods Hole 160: 292-302

Meyer, J. L., Schultz, E. T. (1985). Tissue condition and growth rate of corals associated with schooling fish. Limnol. Oceanogr. 30 (1): 157-166

Oliver, J. K., Chalker, B. E., Dunlap, W. C. (1983). Bathymetric adaptations of reef-building corals at Davies Reef, Great Barrier Reef, Australia, I. Long-term growth responses of Acropora formosa (Dana 1846) J. exp. mar. Biol. Ecol. 73: 11-35

Porter, J. W (1976). Autotrophy, heterotrophy, and resource partitioning in Caribbean corals. Am. Nat. 110: 731-742

Reed, J. K. (1983). Nearshore and shelf-edge Oculina coral reefs: the effects of upwelling on coral growth and on the associated faunal communities. In: Reaka, M. L. (ed.) The ecology of deep and shallow coral reefs. NOAA's undersea research program. Vol. 1 (1). NOAA, Rockville, Maryland, p. 119-124

Schneider, R. C., Smith, S. V. (1982). Skeletal $S_{R}$ content and density in Porites spp. in relation to environmental factors. Mar. Biol. 66: 121-131

Schuhmacher, H. (1984). Reef-building properties of Tubastraea micranthus (Scleractinia, Dendrophylliidae), a coral without zooxanthellae. Mar. Ecol. Prog. Ser. 20: 93-99

Schuhmacher, H., Plewka, M. (1981). The adaptive signifi- cance of mechanical properties versus morphological adjustments in skeletons of Acropora palmata and Acropora cervicornis (Cnidaria, Scleractinia). Proc. 4th Int. Coral Reef Samp., Manila, p. 121-128

Shapiro, A. A. (1980). Skeletal strength of the reef-building elk-horn coral, Acropora palmata. 15th Annual Meeting, Geological Society of America. Abstracts with Programs $12(2): 82$

Smith, F. G. W. (1971). Atlantic reef corals. University of Miami Press, Florida

Stearn, C. W., Scoffin, T, P., Martindale, W. (1977). Calcium carbonate budget of a fringing reef on the west coast of Barbados. Part I. Zonation and productivity. Bull. mar. Sci. 27: $479-510$

Tunnicliffe, V. (1979). The role of boring sponges in coral fracture. In: Levi, C., Bowry-Esnaul, N. (ed.) Biologie des Spongaires. Colloques int. Cent. natn. Rech. scient. 291: 309-315

Tunnicliffe, V. (1983). Caribbean staghom coral populations: pre-hurricane Allen conditions in Discovery Bay, Jamaica. Bull. mar. Sci. 33: 132-151

Vaughan, T. W. (1915). The geological significance of the growth rate of the Floridian and Bahamian shoal-water corals. J. Wash. Acad. Sci. 5: 591-600

Wainwright, S. A., Biggs, W. D., Currey, J. D., Gosline, M. J (1976). Mechanical design in organisms. Wiley, New York

Weber, J. N., Deines, P., Weber, P. H., Baker, P. A. (1976) Depth related changes in the Caribbean reef frame building coral Montastrea annularis. Further implications of a model for stable isotopes fractionation by scleractinian corals. Geochim. cosmochim. Acta 40 (1) : 31-39

Wellington, G. M., Glynn, P. W. (1983). Environmental influences on skeletal banding in Eastern Pacific (Panama) corals. Coral Reefs 1: 215-222

Wellington, G. M., Trench, R. K. (1985). Persistence and coexistence of a non-symbiotic coral in open reef enrivonments. Proc. Natn Acad. Sci. U.S.A. 82: 2432-2436

Wells, J. W. (1973). New and old Scleractinian corals from Jamaica. Bull. mar. Sci. 23: 16-58

Woodley, J. D., Chornesky, E. A., Clifford, P. A., Jackson, J. B C., Kaufman, L. S., Knowlton, N., Lang, J. C., Pearson, M. P., Porter, J. W., Rooney, M. C., Rylaarsdam, K. W. Tunnicliffe, V J., Wahle, C. M., Wulff, J. L., Curtis, A. S. G., Dallmeyer, M. D., Jupp, B. P., Koehl, M. A. R., Neigel J., Sides, E. M. (1981). Hurricane Allen's impact on Jamaican coral reefs. Science 214:749-755 